Submission to Tourism Management

\title{
TWENTY YEARS ON: THE STATE OF CONTEMPORARY ECOTOURISM RESEARCH
}

\author{
DAVID B. WEAVER* \\ LAURA J. LAWTON*
}

School of Hotel, Restaurant and Tourism Management, University of South Carolina, Columbia, SC 29208, USA

Note: Change of Address for Authors

School of Tourism, Leisure, Hotel and Sport Management

Griffith Business School

Griffith University - Gold Coast Campus

QLD 4222, Australia

Tel: +61-(07)-5552-9290

Fax: +61-(07)-5552-8507

E-mail: d.weaver@griffith.edu.au

\begin{abstract}
The ecotourism literature is focused on market segmentation, ecological impacts of wildlife viewing, and community-based ecotourism, but there has been minimal attention to critical areas such as quality control, the industry, external environments or institutions even as the components and parameters of ecotourism are being extended. This imbalance, combined with the fragmentation and lack of integration within the literature, suggest that ecotourism, as a field of academic inquiry, is still in a state of adolescence.
\end{abstract}

Keywords: Ecotourism, Literature review

\section{Introduction}

When the term 'ecotourism' (or sometimes 'eco-tourism') first began to appear regularly in the English-language academic literature in the late 1980s, no one could have predicted the prominent position that this then obscure niche product would come to occupy twenty years later within the tourism sector and more specifically as a topic of 
investigation within the field of tourism studies. Indications of this prominence include the declaration of 2002 as the International Year of Ecotourism (IYE) by the United Nations, and the establishment in that same year of the specialised peer-reviewed Journal of Ecotourism. Ecotourism is now offered as an elective or core subject within many university and college tourism programs, and occasionally as a concentration or degree in its own right. These subjects and programs are supported by an expanding array of textbooks both general in scope (Wearing \& Neil, 1999; Weaver, 2001a, 2001b; Page \& Dowling, 2002; Fennell, 2003) and addressing specific ecotourism topics (Fennell \& Dowling, 2003; Garrod \& Wilson, 2003; Buckley, 2004; Black \& Crabtree, 2007; Zeppel, 2006), and also by more than 400 refereed journal articles as of late 2006 in which ecotourism is the primary focus (as calculated from the publication database leisuretourism.com - see below).

These developments indicate a 'coming of age' for ecotourism as a field of academic enquiry, and it is the purpose of this review to determine to what extent such an assessment is justified. This review is based on the English-language academic literature and peer-reviewed articles in particular, as obtained from the search engine leisuretourism.com, maintained by the UK-based academic publisher CABI Publishing. As of late 2006, this database contained over 75,000 abstracts pertinent to the fields of tourism, leisure, recreation, sport and hospitality, going back to the mid-1970s and derived from more than 6,000 periodicals as well as academic book publisher lists. Coverage of refereed journals in these fields appears inclusive, while articles related to these fields in other disciplines such as geography, economics and ecology are also included in the database (CABI, 2007). The authors searched all titles and abstracts for 
relevant terms such as 'ecotourism', 'eco-tourism', 'ecotourist(s)', 'eco-tourist(s)', 'nature-based tourism', 'nature tourism', 'wildlife watching', 'whale watching', and 'bird watching'. Abstracts were read to eliminate sources in which the coverage of ecotourism was tangential. The remaining sources were consulted by the authors, and organised, based on the abstracts, into interrelated topics as described in Figure 1.

Structured loosely on the chapter organisation of Weaver (2001b), this schemata begins with a basic demand/supply dichotomy, with the latter entailing market segmentation and the former incorporating sub-topics on the nature of ecotourism, venues (mainly protected areas) and the relevant industry. A third topic incorporates specialised and non-specialised institutions, including planning and policy themes. The ecological, economic and socio-cultural impacts of ecotourism constitute a fourth topic that also includes associated quality control mechanisms and the issue of ethics. Finally, Figure 1 includes external environments, both human and biophysical, that affect and are affected by the ecotourism sector. Citations to the literature within these categories are necessarily selective rather than inclusive.

Figure 1 organises the field of ecotourism into five major interrelated subject categories, loosely based on Weaver (2001b). (elaborate) Each will be critically assessed in terms of the research that has been or not been undertaken, and this is followed by an overall assessment of the state of contemporary ecotourism research and its implications for the future development and management of the sector. 


\section{Supply}

\subsection{The nature of ecotourism}

The first sub-category under 'supply' concerns the nature of ecotourism itself. An important indication of the maturation of any field of study is agreement or nearagreement over the terms of reference that pertain to the phenomena of interest and subsequently allow them to be investigated, and knowledge accumulated, in an orderly manner. It is therefore not surprising that the issue of definition constitutes an important theme in the literature, particularly during the 1990s. Fennell (2001), for example, identified 85 definitions of ecotourism and found that value-based dimensions such as conservation, ethics, sustainability, education and community benefits tended to be more prominent in the more recent offerings. There is now near-consensus, thanks largely to the contributions of Blamey $(1997,2001)$, that ecotourism should satisfy three core criteria, i.e., (1) attractions should be predominantly nature-based, (2) visitor interactions with those attractions should be focused on learning or education, and (3) experience and product management should follow principles and practices associated with ecological, socio-cultural and economic sustainability. Each criterion, however, leaves ample room for interpretation, giving rise to ongoing deliberations about the appropriate parameters of each and prompting Weaver (2005a) to identify both a 'minimalist' and 'comprehensive' mode of ecotourism. Ironically, this attainment of something resembling a consensus on criteria (if not definition) has therefore been accompanied by a new theme in the 
literature characterised by attempts to dramatically expand the boundaries of ecotourism beyond its original configuration in the mid-1980s as a nature-based form of alternative tourism. Extreme examples of this involve attempts to challenge the 'consumptive/captive exclusion' principle implicit in most if not all ecotourism definitions. For example, Holland, Ditton and Graefe (1998) and Zwirn, Pinsky and Rahr (2005) argue for the potential inclusion of recreational angling as a form of ecotourism, while Novelli, Barnes and Humavindu (2006) do the same on behalf of trophy hunting. All base their contentions on the purported contributions of these activities to conservation and revenue generation as well as their obvious nature-based focus. With regard to the captive aspect, Ryan and Saward (2004) consider the possibility that zoos re-designed to mimic non-captive habitat could qualify as ecotourism.

It is not yet clear whether such proposals herald a radical re-conceptualisation of ecotourism or are merely an ephemeral curiosity. More certain is the staying power of attempts to expand the boundaries of ecotourism by incorporating more of the cultural component into the attraction mix and by recognising overlaps with conventional mass tourism. The role of affiliated cultural resources as a legitimate secondary attraction in ecotourism has long been recognised. However, a growing tendency to see culture as a core component of the ecotourism attraction mix is discernable, one underlying reason being the failure of terms such as ACE tourism (Adventure, Culture, Ecotourism) (Fennell, 1999) thus far to gain traction as descriptors for nature/culture tourism hybrids. A second factor is the realisation that all supposedly 'natural' environments are directly or at least indirectly affected by human activity, so that 'culture' is therefore implicit and often explicit in all such venues and cannot be divorced from 'nature'. Finally, this latter 
issue has been emphasised in the growing sub-field of 'indigenous' ecotourism, wherein it is argued that centuries of co-existence between indigenous people and their surroundings have profoundly blurred the boundaries between the natural environment and culture (Hinch, 1998, 2001; Nepal, 2004; Zeppel, 2006) (see also section 5.2).

The extension of ecotourism into the realm of conventional mass tourism has its origins in the contention, made as early as the 1980s by Laarman and Durst (1987), that ecotourism exists in both a 'soft' and 'hard' dimension. Although made more commonly in association with markets (see section 3), this distinction has clear implications for products, soft ecotourism being associated with a high level of services and facilities to mediate encounters between venues and potentially large numbers of visitors more casually engaged with the natural environment. The concept of 'mass ecotourism', recognised by Weaver (2001c, 2005b) and Kontogeorgopoulos (2004a) among others to reflect the scale at which such products can occur while allegedly remaining true to core criteria, is rejected by others who contend that ecotourism is essentially a sub-set of alternative tourism (Diamantis \& Ladkin, 1999; Boyd, 2000; Fennell, 2003). This debate influences the issue as to what extent conventional mass tourism can be perceived as an external environment to ecotourism (section 6), and also confounds attempts to ascertain the size and growth of the market (section 3).

Less controversially, the literature has witnessed the emergence of new ecotourism sub-fields with their own attendant issues and themes, the above-mentioned focus on indigenous people being one example. Other high-profile examples include whale watching (which entails cetaceans in general) (Hoyt \& Hvenegaard, 2002; Orams, 2002, 2005; Curtin, 2003; Parsons, Lewandowski \& Lück, 2005), and Antarctic tourism 
(Mason \& Legg, 1999; Stonehouse, 2001; Cloesen, 2003; Stewart, Kirby \& Steel, 2006). As discussed in section 5, both are associated with a relatively high level of engagement with quality control and scientific research. An indication of increasing specialisation is the presentation of bat-based ecotourism as a distinct sub-type by Pennisi, Holland and Stein (2004).

\subsection{Venues}

Virtually all ecotourism case studies involve protected area venues (Antarctica may be considered a type of protected area due to the rigorous provisions of the Antarctic Treaty System), and hence this supply-side topic is de facto the largest subject of research within the literature. However, although several studies have focused on protected areas in general from an ecotourism perspective (Marion \& Farrell, 1998; Lawton, 2001), no effort has apparently yet been made to analyse the case study literature more generally to identify major themes and trends pertinent to the ecotourism/protected area interface. What is apparent even in the absence of such an investigation is that case studies from the less developed countries (LDCs), and those in Latin America, Africa and Southeast Asia in particular, dominate this literature, perhaps in recognition of the degree to which ecotourism can potentially serve as a vehicle for economic development in such areas. With the major exception of Australia, protected area visitation studies in more developed countries (MDCs) tend not to be approached from an ecotourism perspective. Among the few that do is Che (2006), who considers ecotourism-related issues within a lower order protected area in the Alleghany Mountains of Pennsylvania, USA. 
Ecotourism case studies also overwhelmingly occur in conjunction with public protected areas, although private protected areas appear to be emerging as an increasingly popular alternative venue, particularly in Central America and southern Africa. A number of case studies have focused on individual high profile private protected areas such as Monteverde in Costa Rica (Moragrega, 2004), but only a few studies have attempted to address ecotourism issues pertinent more generally to such entities (Langholz, 1996; Langholz et. al. 2000; Barany et al., 2001; Langholz \& Brandon, 2001). An emerging trend is the consideration of venues other than protected areas. Buckley (2004a), for example, found that privately owned land (but not necessarily protected areas) is an extremely important resource for ecotour operators in Australia, but one whose role is poorly understood. In addition, there is a growing interest in considering the ecotourism potential of private and public land that is highly modified (Lawton \& Weaver, 2001), including urban areas (Higham \& Lück, 2002; Dodds \& Joppe, 2003; Weaver, 2005b). This interest is based on the capacity of such space to provide habitat for native wildlife, its proximity to visitors who cannot access more remote sites, its ability to relieve pressure from overcrowded public parks, its ability to provide incentives for rehabilitation, and the relative lack of ecological sensitivity to visitation.

\subsection{Industry}

The ecotourism industry consists of mainly private sector businesses that provide goods and services to ecotourists. An important distinction can be made between specialised ecotourism sectors such as ecolodges, ecotour operators and mediating 
attractions (i.e., canopy walkways, cableways and submarines that facilitate access to otherwise inaccessible areas and are attractions in their own right) and non-specialised sectors such as conventional hotels, cruise lines and travel agencies that incidentally serve ecotourists and/or provide ecotourism products. Operations additionally can be situated along a continuum ranging from micro-businesses to major transnational corporations. Relatively little research has been undertaken on the ecotourism industry, perhaps because LDC sites that dominate the literature tend to follow the communitybased model of service provision that is largely external to this industry (section 5).

A dominant theme in this research is the high failure rate of small specialised ecotourism businesses, and the factors that underly this high rate of attrition, an issue that has been addressed in general terms by McKercher and Robbins (1998) and McKercher (2001). Other studies use specific case studies to obtain further insight into the causes of and solutions to this problem. For example, Mackoy and Osland (2004) found in a survey of ecolodge clients that proximity to natural resources and cost were the two main considerations in product selection and hence business success. However, Osland and Mackoy (2004) also found that scientifically oriented ecolodges judged their success not only by financial performance, but also on whether their clients received appropriate education. Parker and Khare (2005) devised a methodology to assess the factors that make South African ecotourism businesses successful, and found the formation of strong partnerships with local communities to be a critical factor. Hawkins (2004) also emphasised partnerships in finding that small ecotourism businesses in Bulgaria are more successful when they align themselves into competitive clusters. After interviewing operators and public managers in central Pennsylvania (USA), Silva and McDill (2004) 
identified areas of mutual misunderstanding which hampered the ability of the managers to assist the operators. Finally, Dickey and Higham (2005) have demonstrated the advantages of using Geographic Information Systems (GIS) technology to map commercial ecotourism operations in New Zealand in order to better understand the spatial factors that correlate with business performance.

\section{Demand}

\subsection{Ecotourists as a market segment}

Attempts to isolate ecotourists as a distinct set of consumers, as emphasised above, are constrained by disagreements over the parameters of ecotourism itself. As reported by Wight (2001), such research has tended to be undertaken by consultants or government bodies using consumer surveys, and reveals gradations of qualification rather than a dichotomy between ecotourists and non-ecotourists. About one-quarter of Australian consumers, for example, were classified in a Queensland government study in the late 1990s as 'definite' ecotourists based on their travel patterns, preferences and motivations, while another $20 \%$ were 'probable'. Many studies complicate such calculations by considering as 'ecotourists' all visitors to higher order protected areas. However, Hvenegaard and Dearden (1998) found that ecotourists constituted just two of five distinct visitor clusters identified in a Thai National Park. Further study of consumers in general and visitors to protected areas must be undertaken and synthesised to gain a better understanding of the size of the ecotourist market, although the 
boundaries between the latter and consumers in general is likely to remain fuzzy. What is clear from such investigations, however they elect to isolate the 'ecotourist', is the latter's tendency to have higher levels of education and income and to disproportionately originate in MDCs (Eagles \& Cascagnette, 1995; Wight, 1996, 2001). Not surprisingly, individuals engaging in activities clearly differentiated as ecotourism are consistently found to be more environmentally aware and active than other consumers, as demonstrated by a survey of whale watchers in Scotland (Rawles \& Parsons, 2004) and ecolodge patrons in Queensland, Australia (Weaver \& Lawton, 2002). A rare example of longitudinal research in ecotourism is provided by Fennell (2002), who replicated a 1990 survey of Canadian ecotourists in Costa Rica and found comparable behaviour and motivation but significant differences in age and gender.

\subsection{Ecotourist market segmentation}

Allowing that different criteria are still used to distinguish 'ecotourists' from other consumers, a considerable body of research has emerged that attempts to divide the former into distinct sub-groups on the assumption that each will have its own unique set of management implications. From a behavioural perspective, variations of the $\mathrm{soft} / \mathrm{hard}$ model are dominant (e.g., Blamey \& Braithwaite, 1997; Palacio \& McCool, 1997; Diamantis, 1999; Weaver \& Lawton, 2002). An interesting variant in this regard is the 'structured ecotourist' identified by Weaver and Lawton (2002) in a survey of ecolodge guests, who prefer a hard ecotourism experience when interacting with natural attractions, but a soft ecotourism experience at other times (e.g., comfortable 
accommodations and gourmet meals). A further revelation of the increased complexity of the ecotourist market is provided in a study by Eubanks, Stoll and Ditton (2004) that segments USA-based bird watchers into eight sub-types on the basis of different patterns of motivation, behaviour and expenditure.

An emerging issue pertinent to geographic segmentation is the recognition of nontraditional ecotourist markets, especially in East Asia, where annual visitation to protected areas numbers in the hundreds of millions. Studies by Kerstetter, Hou and Lin (2004) and Tao, Eagles and Smith (2004) found Taiwanese ecotourists to differ significantly from European and North American ecotourists, although the use of Eurocentric assessment criteria to make these distinctions reinforces Cater's (2006) assertion that ecotourism is fundamentally a Western construct. Weaver (2002) argues for the existence of a distinctive East Asian type of ecotourist that is attracted to vegetation and geology more than charismatic megafauna (hence Northeast Asia is designated as the 'blossom and waterfall region'), has a strongly aesthetic and philosophical relation to these attractions, and fits well within a disciplined group dynamic. However, no subsequent investigation of this non-Western model of ecotourism has yet been made despite the extremely high levels of apparent participation. From a demographic perspective, another under-studied phenomenon is the growing dominance of females in ecotourism (Wight, 2001), and especially in the more biocentric ecotourist clusters (Weiler \& Richins, 1995; Weaver \& Lawton, 2002). Wight (2001) speculates on possible reasons for this apparent 'feminisation' trend, but as with the Asian model of ecotourism, no empirical research has been undertaken on this issue despite its enormous implications. Highly relevant, however, is the possibility of an 'eco- 
feminist' approach to managing ecotourism raised by Swain and Swain (2004) that recognises the prominent roles played by females both as providers and guests.

\subsection{Interpretation and marketing}

Interpretation and marketing both mediate between the demand and supply sides of ecotourism. The former component has recently received considerable attention in the literature because of its role in facilitating visitor learning and satisfaction as well as positively affecting visitor behaviour both on- and off-site. As to how these outcomes can be achieved has been the subject of an overview by Weiler and Ham (2001) as well as various case studies increasingly focused on the ability of interpretation to effect long term transformations in visitor behaviour (Orams, 1997; Christie \& Moore, 2003; Andersen \& Miller, 2005; Hughes \& Morrison-Saunders, 2005; Tisdell \& Wilson, 2005). A more novel study that merits additional attention because of its implications for the professionalism of the sector is Twidale and Bourne (2003) who analysed interpretive signage at a site in South Australia and conclude that the latter is largely inaccurate and misleading, thereby denying visitors a quality and beneficial learning experience.

Beyond market segmentation (see above), very little attention has been paid in the ecotourism literature to other core aspects of marketing such as promotion and advertising. Two recent content analyses by Price (2003) and Lai and Shafer (2005), however, indicate an extremely serious problem in the industry that must be investigated further. The first of these found that ecotourism operators do not effectively convey their environmental learning opportunities in their advertising, while the second found that 
sustainability practices and credentials of self-proclaimed ecolodges in the Caribbean and Latin America were not being featured in the latter's websites. These studies corroborate Weaver (2007), who found that few operators in Australia having products with advanced certification status under the country's EcoCertification Program featured such credentials on their own websites in such a way as to effectively inform potential customers, even though such certification presumably is sought at least in part to gain competitive advantage in the marketplace.

\section{Institutions}

'Institutions' embody the formal mechanisms, including government policy and plans, specialised and non-specialised organisation, and educational programs explicitly focused on ecotourism. Despite increasing levels of institutional recognition, only a few studies have addressed this topic. Fennell, Buckley and Weaver (2001), for example, provide an overview of the global situation with regard to policies and planning, while Stein, Clark and Rickards (2003) describe how policy formulation in Florida is confounded by the differing priorities of tourism professionals and public land management agency directors. Specifically, the former regarded ecotourism as a way to use protected areas to generate revenue, while the latter were more focused on the role of ecotourism in promoting conservation. Both agreed on the need for policy to recognise the involvement of the community and the private sector.

There is a similar paucity of research on organisations, even though Duffy (2006) describes how the development of ecotourism in Madagascar and by extension other 
LDCs is being increasingly controlled in an era of global governance by a growing array of inter-connected international environmental organisations, many of which in addition are participating in the supply-side of the industry as providers of tours and private protected areas. Butcher $(2005,2006)$ is especially critical of the alleged 'neo-populism' of these organisations, that is, their advocacy of a community 'empowerment' model that favours the preservation of small-scale, traditional lifestyles even though this may not be supported broadly within those communities. The Quebec Declaration arising from the IYE is cited as an embodiment of this patronising approach. A more constructive role is ascribed by Svoronou and Holden (2005) in their study of WWF Greece and its involvement in a rural community-based ecotourism project. Even less attention has been given to the influence and evolution of specialised ecotourism organisations such as The International Ecotourism Society (TIES) and Ecotourism Australia, even though both are characterised by geographically skewed membership profiles and have experienced significant membership declines during the early 2000s (Weaver, 2007). Aside from surveys by Robertson et al. (1996) and Lipscombe and Thwaites (2001), minimal attention has been paid similarly to the evolution and influence of ecotourism-themed academic programs and courses, despite the apparent proliferation of same.

\section{Impacts}

\subsection{Ecological impacts}


One of the most extensive and scientifically rigorous areas of ecotourism research is the effects of human observation on wildlife. Buckley (2004b) provides a useful summary of this research, which has focused on such disparate species as yellow-eyed penguins (McClung et al., 2004), hoatzins (Müllner, Linsenmair \& Wikelski, 2004), bottlenose dolphins (Constantine, Brunton \& Dennis, 2004), and woodland caribou (Duchesne, Côté \& Barrette, 2000). Not surprisingly, most of these studies isolate distance between the viewer and the viewed as the single most critical variable affecting wildlife stress, although Fowler (1999) found no measurable effects of viewing on Magellanic penguins and Nevin and Gilbert (2004) concluded that female brown bears in British Columbia actually benefited from proximity to humans since this helped them to avoid encounters with aggressive male bears.

Despite the essential nature of this research to the management of the ecotourism experience, almost none of the empirical studies has been undertaken by tourism specialists or is found in specialised tourism journals. Rather, just one scientific journal Biological Conservation - appears to account for most of them. This discrepancy is at least tangentially addressed by Rodger and Moore (2004), who describe how the perceptions and goals of scientists differ from ecotourism site managers and operators in terms of the purpose of such research. The lack of wildlife impact study research from within the tourism field, however, is not to suggest that the latter has been inactive in the broader area of ecological impact. Recent contributions, which tend to be more holistic in orientation, include a discussion by Hunter and Shaw (2005) of ecological footprinting (EF) applications to various ecotourism scenarios, and the use of case studies in South Africa and Belize to demonstrate the potential of ecotourism to encourage habitat 
restoration (Blangy \& Mehta, 2006). An emerging research theme related to the latter is the role that volunteer ecotourists can play in the on-site maintenance and enhancement of wildlife habitat, as examined by Weiler and Richins (1995) in the case of Earthwatch Australia, Davies (2002) in respect to Conservation Volunteers Australia, and Galley and Clifton (2004) with regard to Operation Wallacea in Indonesia. Fennell and Weaver (2005) propose the establishment of a network of 'ecotouriums' consisting of existing protected areas in which visitors would play a major personal role in enhancing and rehabilitating park habitat.

\subsection{Socio-cultural impacts}

As with ecological impacts, there is a specific area related to socio-cultural impacts that has also spawned a discernable cluster of research activity. In this case, community-based ecotourism $(\mathrm{CBE})$ is touted as a potential solution that benefits ecosystems as well as local residents through community empowerment. Most related studies are careful not to tout $\mathrm{CBE}$ as a panacea, but identify factors such as internal collaboration, external partnerships, secure access to venues and effective leadership that associate with success (commonly defined as the generation and equitable distribution of surplus revenue) (Scheyvens, 1999; Goodwin, 2002; Vincent \& Thompson, 2002; Yaman \& Mohd, 2004; Zografos \& Oglethorpe, 2004; Charnley, 2005; Fuller, Buultjens \& Cummings, 2005; Kontogeorgopoulos, 2005; Stone \& Wall, 2005; Cusack \& Dixon, 2006; Lai \& Nepal, 2006; Morais et al, 2006). Almost all of these studies are based on LDC case studies, often but not always involving indigenous people and/or ethnographic 
research methods. A critical aspect is also evident in this cluster, as demonstrated by Butcher's criticism of organisation neopopulism described in section 4 above. In addition, Jones (2005) discusses the importance of 'social capital' in CBE projects in The Gambia, but stresses that this can be jeopardised if structural social capital (what people do) does not coincide with what people actually feel (i.e., cognitive social capital). Other issues include the potential to generate internal conflict (Hernandez Cruz, 2005; Southgate, 2006), exacerbate discrepancies in class, gender and patronage (Belsky, 1999), create problems as to who should be included as part of the 'community' (Medina, 2005) and create long-term dependency on external support (Kiss, 2004; Southgate, 2006).

Within those studies that focus on indigenous people, there is an emerging subcluster that considers empowerment issues unique to such cultures. This emphasis on 'indigenousness' includes the use of ecotourism as a political tool to gain sympathy and endorsement for indigenous causes from visitors and present to them a positive identity, demonstrate long-term indigenous occupation and use of a particular area, and otherwise reinforce legal claims on these areas (Zografos \& Kenrick, 2005 in the case of Ecuador, Johnston, 2000). Given the above, and to the extent that indigenous people in Australia, Canada, New Zealand and elsewhere are reasserting claims to large areas beyond their designated reserved land and are demanding to participate in the management of parks and other sites within those areas, 'indigenousness' is a topic that is likely to attract more research within the ecotourism field.

\subsection{Economic impacts}


Much of the earliest ecotourism-related research, dating back to the 1970s, was concerned with establishing the monetary value conferred on lions and other charismatic megafauna by their use as objects of observation (see Sherman \& Dixon, 1990). A successor topic sporadically investigated in the early 2000s is contingent valuation (CV) which considers the amount a target audience is willing to pay to use or not use a particular environmental service. Applications include the calculation of a high entry fee at an ecotourism site in Ghana (Navrud \& Vondolia, 2005) and a high price that inbound tourists in China were willing to pay to see giant pandas in their natural habitat (Kontoleon et al., 2002). CV has also been used to determine that manatee protection in Florida is more economically rational because of its ecotourism implications than degrading or destroying manatee habitat to facilitate development (Solomon, Corey-Luse \& Halvorsen, 2004). The travel cost (TC) method variant was used by Menkhaus and Lober (1996) to estimate the willingness of US tourists to visit Monteverde Cloud Forest Reserve in Costa Rica, while the CV and TC methods were both used to demonstrate the importance of flamingos in attracting tourists to a national park in Kenya (Navrud \& Mungatana, 1994).

A supply-side emphasis is evident in Wunder (2000), who calculated the income obtained from ecotourism by indigenous communities in Ecuador and concluded that these amounts serve as a conservation incentive. Earlier, Lindberg, Enriquez and Sproule (1996) demonstrated this incentive effect by showing how communities in Belize became more supportive of proximate protected areas as their income from park-based ecotourism increased. Overviews of economic methodologies useful for ecotourism 
planning are provided by Herath (2002) and Lindberg (2001), with the latter emphasising a number of studies from the 1990s that used input/output (IO) analysis to calculate indirect and direct economic benefits. More unorthodox because of its holistic approach is Gössling (1999), who introduces the concept of Environmental Damage Costs into the cost/benefit analyses of ecotourism in recognition of the climate change that is being exacerbated by transit-related aircraft emissions.

\subsection{Quality control and ethics}

Quality control mechanisms are means of assuring that products and services comply with stipulated standards of excellence, which in ecotourism usually relate to the principles and practices of sustainability. Since the latter is a core imperative of ecotourism, effective quality control is a crucial means through which the sector can gain legitimacy among consumers and contend with the problem of 'greenwashing'. The lack of research into this topic is therefore surprising. Among the few relevant studies are Sirakaya (1997) and Sirakaya and Uysal (1997), who found that education and appeals of ethical behaviour were more effective among US-based ecotour operators in attaining compliance to code of conduct guidelines than sanctions or enforcement. More important for achieving professionalism, however, are certification programs based on third party auditing and verification of compliance to rigorous indicator benchmarks (Wearing, 1995; Black \& Crabtree, 2007). The fact that Australia is one of the only countries to have a specialised ecotourism certification program helps to explain the paucity of research on this topic. Black and Ham (2005) surveyed a variety of stakeholder groups to 
assess the suitability of the Australian EcoGuide Program as a basis for certification, but no studies to these reviewers' knowledge have as of yet empirically examined consumer awareness or acceptance of Australia's best practice EcoCertification Program, which is serving as a prototype for a global certification standard. Few studies, similarly, have attempted to identify or quantify the indicators that form the basis for sustainable management, Li's (2004) proposed indicator set for China's Nature Reserves being one exception.

The broader issue of ethics pervades the assessment of ecotourism impacts, with Jaakson (1997) accordingly arguing for the recognition of a distinctive and pervasive 'ethic of ecotourism', and Donohoe and Needham (2006) situating ethics as a core definitional criterion. Quality control, for example is related to ethical behaviour in part because all mechanisms rely to some extent on accurate self-reporting and assessment. Given the apparent problem of greenwashing in the sector (an assertion, however, that is not yet supported empirically) and building on the early speculations of Wight (1993, 1995), Malloy and Fennell (1998) have proposed a framework for assessing the ethics of ecotourism organisations. Fennell and Malloy (1999), moreover, found that ecotourism operators were more likely than those in other fields of tourism to proclaim an adherence to ethical behaviour. Research is lacking, however, as to whether such expressions of compliance translate into actual compliance. Other studies dealing explicitly with ethics include Buckley (2005) who explores the ethical dilemma associated with narwhal watching in the Canadian Arctic, wherein visitor perceptions of the species as a protected icon often conflict with local residents' practice of hunting and consuming narwhal as part of their traditional lifestyle. 


\section{External Environments}

The literature does not reflect the truism that all ecotourism is profoundly affected by external cultural and geophysical forces. One area where engagement is evident is the relationship with 3S (sea, sand and sun) tourism. As discussed earlier, the boundary between soft ecotourism and conventional mass tourism is fuzzy, and there is increased speculation as to the convergence of the two (Ayala, 1995; Sharpley, 2006). Kontogeorgopoulos (2004), additionally, demonstrates how ecotourism in Phuket, Thailand is structurally dependent on mass $3 \mathrm{~S}$ tourism, while Johnson (2006) analyses how ecotourism-based shore excursions in the Caribbean are an increasingly important component of the mass cruising experience. Less understood is the relationship between ecotourism and extractive activities such as recreational hunting and fishing, assuming that the latter do not qualify as ecotourism. While the potential for conflict is reduced in high order protected areas that prohibit recreational hunting and fishing, lower order venues such as US National Forests are expected to accommodate and satisfy extractive as well as non-extractive recreational activities.

The research that considers the impacts of external factors other than those related to tourism is extremely sparse. Examples include Ospina (2006) who examines the relationship between war and ecotourism in the national parks of Colombia, and Amerom (2006) who considers the effects of foreign relations on ecotourism in South Africa. A relevant study by Yu, Hendrickson and Castillo (1997) describes the negative effects of agricultural colonisation on an ecolodge in the Amazon region of Peru. In the 
geophysical realm, Preston-Whyte and Watson (2005) contribute to the growing body of research on the effects of climate change on tourism by examining the implications of the aridification of the savannahs that support Sub-Saharan Africa's safari-based ecotourism industry.

\section{Conclusions}

A decade has passed since Lawrence, Wickins and Phillips (1997) suggested that ecotourism was experiencing a 'crisis of legitimacy' in terms of its ability to achieve its alleged ecological and economic goals, and since Lindberg and McKercher (1997) described ecotourism as a maturing field whose capacity to meet its ascribed objectives was still unclear. During that subsequent ten years, at least 300 refereed Englishlanguage journal articles and an equally large number of books and book chapters have been contributed to the expanding ecotourism literature. It is not the purpose of this article to determine whether the goals of ecotourism are now being achieved, but rather to assess the extent to which the relevant academic literature is engaged in investigating the phenomenon of ecotourism so that those goals can be achieved.

At least three research 'macro-themes' can be detected in the above review. First, having achieved near consensus on the core criteria of ecotourism, attempts at both segmentation and expansion of the subject are evident along multiple fronts involving products, venues, activities and markets. While the inclusion of hunting and fishing may be over-reaching, there is increased recognition of the reality and potential of mass ecotourism, ecotourism in which cultural attractions are more prominent, and ecotourism 
in highly modified spaces outside of protected areas. The bifurcation of ecotourism into hard and soft dimensions is perhaps the best example of a prominent trend in the literature that implicates both the segmentation and expansion of the field. An associated managerial challenge is the blurring of lines between 'ecotourism' and other forms of tourism, which can lead to problems of jurisdictional, marketing and product development overlap and confusion. Second, there is a persistent effort to understand the impacts of ecotourism, albeit along four separate trajectories of research. One is a 'hard scientific' path focused on the effects of viewing on particular wildlife species, while the others investigate the potential for community-based models to optimise socio-cultural impacts, focus econometrically on various aspects of the incentive effect, and consider the ethical dimensions of ecotourism impacts. Third, the literature both reflects and reveals a deep 'North-South' divide within the sector itself, wherein venues and community-based models are dominated by LDC-based case studies while case studies on markets, the industry and institutions are overwhelmingly MDC-based, as is the authorship of most of the ecotourism literature.

Beyond these three themes, there are strategically important areas of ecotourism that are conspicuous by their paucity in the literature. These include the issue of greenwashing, even though this is frequently alleged to be a major problem that undermines the credibility of the sector; the actions and influence of institutions, despite the fact that ecotourism since the mid-1990s has become increasingly institutionalised and the success of many community-based projects is dependent on MDC-based environmental organisations; quality control and affiliated indicators, even though these are key to assuring that ecotourism products actually meet their social and ecological 
expectations and are adequately differentiated from products that do not meet appropriate standards; the industry, even though private sector businesses (specialised and nonspecialised) dominate the sector in all areas except community-based ecotourism and institutions; and the influence of external environments, despite the enormous influence that these obviously exercise over ecotourism. An interesting situation pertains to protected areas since these are implicated in almost all of the empirical supply-side studies but have not been properly addressed as an ecotourism topical focus in its own right.

The expanding ecotourism literature, therefore, is imbalanced but also fragmented in that particular topical areas are not well informed by or connected to the research in other topical areas or even within a given topic. The ecological impact literature, for example, is not at all linked to the research on socio-cultural impacts as manifested in the community-based ecotourism literature. Neither in turn is connected to the literature on interpretation, the industry, or market segmentation. Fragmentation is also evident in the absence of longitudinal studies or of research that tests outcomes from prior empirical research. Imbalance and fragmentation are characteristics that may persist for multiple reasons, including 'normative' factors such as mutual citation cliques, funding priorities, and disciplinary or ideological self-isolation, as well as the simple fact that ecotourism is still in a relative state of adolescence. No extraordinary crisis of credibility or legitimacy is therefore necessarily indicated. Still, it behooves the academic community to proactively address these weaknesses by paying more attention to the neglected topic areas and by encouraging integration and continuity of research within and among all topic areas - in other words, an interdisciplinary approach. The establishment of the 
Journal of Ecotourism as a specialised forum is a positive move in this direction, as would be the formation of a cross-disciplinary academic ecotourism association. From a managerial perspective, it is also important to gauge the extent to which practitioners and other decision-makers are actually being informed by the expanding ecotourism literature, to identify and address topics that are of actual concern to the non-academic community, and to ensure that the outcomes of such research are made accessible to the latter. This should help to create a symbiosis between the academic and non-academic ecotourism communities that cannot but facilitate the positive progression of both.

\section{References}

Amerom, M. van (2006). African foreign relations as a factor in ecotourism development: the case of South Africa. Journal of Ecotourism, 5, 112-127.

Andersen, M. \& Miller, M. (2005). Onboard marine environmental education: whale watching in the San Juan Islands, Washington. Tourism in Marine Environments, $2,111-118$.

Ayala, H. (1995). From quality product to eco-product: will Fiji set a precedent? Tourism Management, 16, 39-47.

Barany, M., Hammett, A., Shillington, L. \& Murphy, B. (2001). The role of private wildlife reserves in Nicaragua's emerging ecotourism industry. Journal of Sustainable Tourism, 9, 95-110.

Belsky, J. (1999). Misrepresenting communities: the politics of community-based rural ecotourism in Gales Point Manatee, Belize. Rural Sociology, 64, 641-666. 
Black, R. \& Crabtree, A. Eds. (2007). Quality Assurance and Certification in Ecotourism. Wallingford, UK: CABI.

Black, R. \& Ham, S. (2006). Improving the quality of tour guiding: towards a model for tour guide certification. Journal of Ecotourism, 4, 178-195.

Blamey, R. (1997). Ecotourism: the search for an operational definition. Journal of Sustainable Tourism, 5, 109-130.

Blamey, R. (2001). Principles of ecotourism. In D. Weaver, D. Encyclopedia of Ecotourism (pp. 5-22). Wallingford, UK: CAB International.

Blamey, R. \& Braithwaite, V. (1997). A social values segmentation of the potential ecotourism market. Journal of Sustainable Tourism, 5, 29-45.

Blangy, S. \& Mehta, H. (2006). Ecotourism and ecological restoration. Journal for Nature Conservation, 14, 233-236.

Boyd, S. (2000). Tourism, national parks and sustainability. In R. Butler \& S. Boyd, S. Tourism and National Parks: Issues and Implications (pp. 161-186). Chichester, UK: Wiley.

Buckley, R. (2004a). Ecotourism land tenure and enterprise ownership: Australian case study. Journal of Ecotourism, 3, 208-213.

Buckley, R. Ed. (2004b). Environmental Impacts of Ecotourism. Wallingford, UK:

\section{CABI.}

Buckley, R. (2005). In search of the narwhal: ethical dilemmas in ecotourism. Journal of Ecotourism, 4, 129-134.

Butcher, J. (2005). The moral authority of ecotourism: a critique. Current Issues in Tourism, 8, 114-124. 
Butcher, J. (2006). The United Nations International Year of Ecotourism: a critical analysis of development implications. Progress in Development Studies, 6, 146156.

CABI. (2007). Leisure Tourism Database. http://www.leisuretourism.com/about.asp.

Cater, E. (2006). Ecotourism as a Western construct. Journal of Ecotourism, 5, 23-39.

Charnley, S. (2005). From nature tourism to ecotourism? The case of the Ngorongoro Conservation Area, Tanzania. Human Organization, 64, 75-88.

Che, D. (2006). Developing ecotourism in First World, resource-dependent areas. Geoforum, 37, 212-226.

Christie, M. \& Mason, P. (2003). Transformative tour guiding: training tour guides to be critically reflective practitioners. Journal of Ecotourism, 2, 1-16.

Cloesen, U. (2003). Environmental impact management of ship based tourism to Antarctica. Asia Pacific Journal of Tourism Research, 8, 32-37.

Constantine, R., Brunton, D. \& Dennis, T. (2004). Dolphin-watching tour boats change bottlenose dolphin (Tursiops truncates) behaviour. Biological Conservation, 117, 299-307.

Curtin, S. (2003). Whale-watching in Kaikoura: sustainable destination development? Journal of Ecotourism, 3, 173-195.

Cusack \& Dixon (2006). Community-based ecotourism and sustainability: cases in Bocas del Toro Province, Panama and Talamanca, Costa Rica. Journal of Sustainable Forestry, 22, 157-182. 
de la Torre, S., Snowdon, C. \& Beharano, M. 2000. Effects of human activities on wild pygmy marmosets in Ecuadorian Amazonia'. Biological Conservation, 94, 153163.

Diamantis, D. (1999). The characteristics of UK's ecotourists. Tourism Recreation Research, 24, 99-102.

Diamantis, D. \& Ladkin, A. (1999). The links between sustainable tourism and ecotourism: a definitional and operational perspective. Journal of Tourism Studies, 10 (2), 35-46.

Dickey, A. \& Higham, J. (2005). A spatial analysis of commercial ecotourism businesses in New Zealand: a c 1999 benchmarking exercise using GIS. Tourism Geographies, 7, 373-388.

Dixon, J. \& Sherman, P. (1990). Economics of Protected Areas. Washington, DC: Island Press.

Dodds, R. \& Joppe, M. (2003). The application of ecotourism to urban environments. Tourism, 51, 157-164.

Donohoe, H. \& Needham, R. (2006). Ecotourism: the evolving contemporary definition. Journal of Ecotourism, 5, 192-210.

Duchesne, M., Côté, S. \& Barrette, C. (2000). Responses of woodland caribou to winter ecotourism in the Charlevoix Biosphere Reserve, Canada. Biological Conservation, 96, 311-317.

Duffy, R. (2006). Global environmental governance and the politics of ecotourism in Madagascar. Journal of Ecotourism, 5, 128-144. 
Eagles, P. \& Cascagnette, J. (1995). Canadian ecotourists: who are they? Tourism Recreation Research, 20, 22-28.

Eubanks, T., Stoll, J. \& Ditton, R. (2004). Understanding the diversity of eight birder sub-populations: socio-demographic characteristics, motivations, expenditures and net benefits. Journal of Ecotourism, 3, 151-172.

Fennell, D. (1999). Ecotourism: An Introduction. First edition. London: Routledge.

Fennell, D. (2001). A content analysis of ecotourism definitions. Current Issues in Tourism, 4, 403-421.

Fennell, D. (2002). The Canadian ecotourist in Costa Rica: ten years down the road. International Journal of Sustainable Development, 5, 282-295.

Fennell, D. (2003). Ecotourism: An Introduction. Second edition. London: Routledge. Fennell, D., Buckley, R. \& Weaver, D. (2001). Ecotourism policy and planning. In D. Weaver Encyclopedia of Ecotourism (pp. 463-477). Wallingford, UK: CAB International.

Fennell, D. \& Dowling, R. Eds. (2003). Ecotourism Policy and Planning. Wallingford, UK: CABI.

Fennell, D. \& Malloy, D. (1999). Measuring the ethical nature of tourism operators. Annals of Tourism Research, 26, 928-943.

Fennell, D. \& Weaver, D. (2005). The ecotourium concept and tourism-conservation symbiosis. Journal of Sustainable Tourism, 13, 373-390.

Fowler, G. (1999). Behavioral and hormonal responses of Magellanic penguins (Spheniscus Magellanicus) to tourism and nest site visitation. Biological Conservation, 90, 143-149. 
Fuller, D., Buultjens, J. \& Cummings, E. (2005). Ecotourism and indigenous microenterprise formation in northern Australia opportunities and constraints. Tourism Management, 26, 891-904.

Galley, G. \& Clifton, J. (2004). The motivational and demographic characteristics of research ecotourists: Operation Wallacea volunteers in southeast Sulawesi, Indonesia. Journal of Ecotourism, 3, 69-82.

Garrod, B. \& Wilson, J. Eds. (2003). Marine Ecotourism: Issues and Experiences. Clevedon, UK: Channel View.

Goodwin, H. (2002). Local community involvement in tourism around National Parks: opportunities and constraints. Current Issues in Tourism, 5, 338-360.

Gössling, S. (1999). Ecotourism: a means to safeguard biodiversity and ecosystem functions? Ecological Economics, 29, 303-320.

Hawkins, D. (2004). A protected areas ecotourism competitive cluster approach to catalyse biodiversity conservation and economic growth in Bulgaria. Journal of Sustainable Tourism, 12, 219-244.

Herath, G. (2002). Research methodologies for planning ecotourism and nature conservation. Tourism Economics, 8, 77-101

Hernandez Cruz, R., Bello Baltazar, E., Montoya Gomez, G. \& Estrada Lugo, E. (2005). Social adaptation: ecotourism in the Lacandon forest. Annals of Tourism Research, 32, 610-627.

Higham, J. \& Lück, M. (2002). Urban ecotourism: a contradiction in terms? Journal of Ecotourism, 1, 36-51. 
Hinch, T. (1998). Ecotourists and indigenous hosts: diverging views on their relationship with nature. Current Issues in Tourism, 1, 120-124.

Hinch, T. (2001). Indigenous territories. In D. Weaver, D. Encyclopedia of Ecotourism (pp. 345-357). Wallingford, UK: CAB International.

Holland, S., Ditton, R. \& Graefe, A. (1998). An ecotourism perspective on billfish fisheries. Journal of Sustainable Tourism, 6, 97-116.

Hoyt, E. \& Hvenegaard, G. (2002). A review of whale-watching and whaling with applications for the Caribbean. Coastal Management, 30, 381-399.

Hughes, M. and Morrison-Saunders, A. (2005). Influence of on-site interpretation intensity on visitors to natural areas. Journal of Ecotourism, 4, 161-177.

Hunter, C. \& Shaw, J. (2005). Applying the ecological footprint to ecotourism scenarios. Environmental Conservation, 32, 294-304.

Hvenegaard, G. \& Dearden, P. (1998). Ecotourism versus tourism in a Thai National Park. Annals of Tourism Research, 25, 700-720.

Jaakson, R. (1997). Exploring the epistemology of ecotourism. Journal of Applied Recreation Research, 22, 33-47.

Johnson, D. (2006). Providing Ecotourism Excursions for Cruise Passengers. Journal of Sustainable Tourism, 14, 43-54.

Johnston, A. (2000). Indigenous peoples and ecotourism: bringing indigenous knowledge and rights into the sustainability equation. Tourism Recreation Research, 89-96.

Jones, S. (2005). Community-based ecotourism - the significance of social capital. Annals of Tourism Research, 32, 303-324. 
Kerstetter, D., Hou, J. \& Lin, C. (2004). Profiling Taiwanese ecotourists using a behavioral approach. Tourism Management, 25, 491-498.

Kiss, A. (2004). Is community-based ecotourism a good use of biodiversity conservation funds? Trends in Ecology and Evolution, 19, 232-237.

Kontogeorgopoulos, N. (2004a). Ecotourism and mass tourism in southern Thailand: spatial interdependence, structural connections, and staged authenticity. GeoJournal, 61, 1-11.

Kontogeorgopoulos, N. (2004b). Conventional tourism and ecotourism in Phuket, Thailand: conflicting paradigms or symbiotic partners? Journal of Ecotourism, 3, $87-108$.

Kontogeorgopoulos, N. (2005). Community-based ecotourism in Phuket and Ao Phangnga, Thailand: partial victories and bittersweet remedies. Journal of Sustainable Tourism, 13, 4-23.

Kontoleon, A., Swanson, T., Wang, Q., Xuejun, Q. \& Yang, C. (2002). Optimal ecotourism: the economic value of the Giant Panda in China. In C. Pearce \& C. Palmer Valuing the Environment in Developing Countries: Case Studies (pp. 206235). Cheltenham, UK: Edward Elgar.

Laarman, J. \& Durst, P. (1987). Nature Travel and Tropical Forests. FREI Working Paper Series. Raleigh, NC, USA: Southeastern Center for Forest Economics Research, North Carolina State University.

Lai, P. \& Nepal, S. (2006). Local perspectives of ecotourism development in Tawushan Nature Reserve, Taiwan. Tourism Management, 27, 1117-1129. 
Lai, P. \& Shafer, S. (2005). Marketing ecotourism through the Internet: an evaluation of selected ecolodges in Latin America and the Caribbean. Journal of Ecotourism, 4, 143-160.

Langholz, J. (1996). Economics, objectives, and success of private nature reserves in Sub-Saharan Africa and Latin America. Conservation Biology, 10, 271-280.

Langholz, J. \& Brandon, K. (2001). Ecotourism and privately owned protected areas. In D. Weaver Encyclopedia of Ecotourism (pp. 303-314). Wallingford, UK: CAB International.

Langholz, J., Lassoie, J., Lee, D. \& Chapman, D. (2000). Economic considerations of privately owned parks. Ecological Economics, 33, 173-183.

Lawrence, T., Wickins, D. \& Phillips, N. (1997) Managing legitimacy in ecotourism. Tourism Management, 18, 307-316.

Lawton, L. (2001). Ecotourism in public protected areas. In D. Weaver Encyclopedia of Ecotourism (pp. 287-302). Wallingford, UK: CAB International.

Lawton, L. \& Weaver, D. (2001). Ecotourism in modified spaces. In D. Weaver Encyclopedia of Ecotourism (pp. 315-326). Wallingford, UK: CAB International.

Li, W. (2004). Environmental management indicators for ecotourism in China's nature reserves: a case study in Tianmushan Nature Reserve. Tourism Management, 25, 559-564.

Lindberg, K. (2001). Economic impacts. In D. Weaver Encyclopedia of Ecotourism (pp. 363-377). Wallingford, UK: CAB International.

Lindberg, K., Enriquez, J. \& Sproule, K. (1996). Ecotourism questioned: case studies from Belize. Annals of Tourism Research, 23, 543-562. 
Lindberg, K. \& McKercher, B. (1997). Ecotourism: a critical overview. Pacific Tourism Review, 1, 65-79.

Lipscombe, N. \& Thwaites, R. (2001). Education and training. In D. Weaver Encyclopedia of Ecotourism (pp. 627-638). Wallingford, UK: CAB International. Mackoy, R. \& Osland, G. (2004). Lodge selection and satisfaction: attributes valued by ecotourists. Journal of Tourism Studies, 15, 13-25.

Malloy, D. \& Fennell, D. (1998). Ecotourism and ethics: moral development and organizational cultures. Journal of Travel Research, 36, 47-56.

Marion, J. \& Farrell, T. (1998). Managing ecotourism visitation in protected areas. In K. Lindberg, M. Epler Wood \& D. Engeldrum, D. Ecotourism: A Guide for Planners and Managers. Volume 2. (pp. 155-181). North Bennington, VT, USA: The Ecotourism Society.

Mason, P. \& Legg, S. (1999). Antarctic tourism: activities, impacts, management issues, and a proposed research agenda. Pacific Tourism Review, 3, 71-84.

McClung, M., Seddon, P., Massaro, M. \& Setiawan, A. (2004). Nature-based tourism impacts on yellow-eyed penguins Megadyptes antipodes: does unregulated visitor access affect fledging weight and juvenile survival? Biological Conservation, $119,279-285$.

McKercher, B. (2001). The business of ecotourism. In D. Weaver Encyclopedia of Ecotourism (pp. 565-577). Wallingford, UK: CAB International.

McKercher, B. \& Robbins, B. (1998). Business development issues affecting naturebased tourism operators in Australia. Journal of Sustainable Tourism, 6, 173-188. 
Medina, L. (2005). Ecotourism and certification: confronting the principles and pragmatics of socially responsible tourism. Journal of Sustainable Tourism, 13, 281-295.

Menkhaus, S. \& Lober, D. (1996). International ecotourism and the valuation of tropical rainforests in Costa Rica. Journal of Environmental Management, 47, 1-10.

Moragrega, M. (2004). Tourist expansion and development of rural communities - the case of Monteverde, Costa Rica. Mountain Research and Development, 24, $202-$ 205.

Morais, D., Zhu C., Dong E., \& Yang G. (2006). Promoting sustainability through increased community involvement: the Shangri-La Ecotourism Demonstration Project. Tourism Review International, 10, 131-140.

Müllner, A. Linsenmair, K. \& Wikelski, M. (2004). Exposure to ecotourism reduces survival and affects stress response in hoatzin chicks (Opisthocomus hoazin). Biological Conservation, 118, 549-558.

Navrud, S. \& Mungatana, E. (1994). Environmental valuation in developing countries: the recreational value of wildlife viewing. Ecological Economics, 11, 135-151.

Navrud, S. \& Vondolia, G. (2005). Using contingent valuation to price ecotourism sites in developing countries. Tourism, 53, 115-125.

Nepal, S. (2004). Indigenous ecotourism in central British Columbia: the potential for building capacity in the Tl'azt'en Nations territories. Journal of Ecotourism, 3, 173-194. 
Nevin, O. \& Gilbert, B. (2005). Measuring the cost of risk avoidance in brown bears: further evidence of positive impacts of ecotourism. Biological Conservation, 123, 453-460.

Novelli, M., Barnes, J. \& Humavindu, M. (2006). The other side of the ecotourism coin: consumptive tourism in Southern Africa. Journal of Ecotourism, 5, 62-79.

Orams, M. (1997). The effectiveness of environmental education: can we turn tourists into "greenies"? Progress in Tourism and Hospitality Research, 3, 295-306.

Orams, M. (2002). Marine ecotourism as a potential agent for sustainable development in Kaikoura, New Zealand. International Journal of Sustainable Development, 5, $338-352$.

Orams, M. (2005). Dolphins, whales and ecotourism in New Zealand: what are the impacts and how should the industry be managed? In C. Hall \& S. Boyd, S. Nature-based Tourism in Peripheral Areas: Development or Disaster? (pp. 231245). Clevedon, UK: Channel View.

Osland, G. \& Mackoy, R. (2004). Ecolodge performance goals and evaluation. Journal of Ecotourism, 3, 109-128.

Ospina, G. (2006). War and ecotourism in the National Parks of Colombia: some reflections on the public risk and adventure. International Journal of Tourism Research, 8, 241-246.

Palacio, V. \& McCool, S. (1997). Identifying ecotourists in Belize through benefit segmentation: a preliminary analysis. Journal of Sustainable Tourism, 5, 234243.

Page, S. \& Dowling, R. (2002). Ecotourism. London: Pearson Education. 
Parker, S. \& Khare, A. (2005). Understanding success factors for ensuring sustainability in ecotourism development in southern Africa. Journal of Ecotourism, 4, 32-46.

Parsons, E., Lewandowski, J. \& Lück, M. (2005). Recent advances in whale-watching research: 2004-2005. Tourism in Marine Environments, 2, 119-132.

Pennisi, L., Holland, S. \& Stein, T. (2004). Achieving bat conservation through tourism. Journal of Ecotourism, 3, 195-207.

Preston-Whyte, R. \& Watson, H. (2005). Nature tourism and climatic change in Southern Africa. In C.M. Hall \& J. Higham, Tourism, Recreation and Climate Change (pp. 130-142). Clevedon, UK: Channel View.

Price, G. (2003). Ecotourism operators and environmental education: enhancing competitive advantage by advertising environmental learning experiences. Tourism Analysis, 8, 143-147.

Rawles, C. \& Parsons, E. (2004). Environmental motivation of whale-watching tourists in Scotland. Tourism in Marine Environments, 1, 129-132.

Robertson, Dawson, C., Kuentzel, W. \& Selin, S. (1996). College and university curricula in ecotourism and nature-based tourism. Journal of Natural Resources and Life Sciences Education, 25, 152-155.

Rodger, K. \& Moore, S. (2004). Bringing science to wildlife tourism: the influence of managers' and scientists' perceptions. Journal of Ecotourism, 3, 1-19.

Ryan, C. \& Saward, J. (2004). The zoo as ecotourism attraction - visitor reactions, perceptions and management implications: the case of Hamilton Zoo, New Zealand. Journal of Sustainable Tourism, 12, 245-266. 
Scheyvens, R. (1999). Ecotourism and the empowerment of local communities. Tourism Management, 20, 245-249.

Sharpley, R. (2006). Ecotourism: a consumption perspective. Journal of Ecotourism, 5, $7-22$.

Silva, G. \& McDill, M. (2004). Barriers to ecotourism supplier success: a comparison of agency and business perspectives. Journal of Sustainable Tourism, 12, 289-305.

Sirakaya, E. (1997). Attitudinal compliance with ecotourism guidelines. Annals of Tourism Research, 24, 919-950.

Sirakaya, E. \& Uysal, M. (1997). Can sanctions and rewards explain conformance behaviour of tour operators with ecotourism guidelines? Journal of Sustainable Tourism, 5, 322-332.

Solomon, B., Corey-Luse, C. \& Halvorsen, K. (2004). The Florida manatee and ecotourism: toward a safe minimum standard. Ecological Economics, 50. 101-115.

Southgate, C. (2006). Ecotourism in Kenya: the vulnerabilities of communities. Journal of Ecotourism, 5, 80-96.

Stein, T., Clark, J. \& Rickards, J. (2003). Assessing nature's role in ecotourism development in Florida: perspectives of tourism professionals and government decision-makers. Journal of Ecotourism, 2, 155-172.

Stewart, E., Kirby, V. \& Steel, G. (2006). Perceptions of Antarctic tourism: a question of tolerance. Landscape Research, 31, 193-214.

Stone, M. \& Wall, G. (2005). Ecotourism and community development: the case of Jianfengling National Forest Park, Hainan, China. China Tourism Research, 1, 78-100. 
Stonehouse, B. (2001). Polar environments (Arctic and Antarctic). In D. Weaver Encyclopedia of Ecotourism (pp. 219-234). Wallingford, UK: CAB International.

Svoronou, E. and Holden, A. (2005). Ecotourism as a tool for nature conservation: the role of WWF Greece in the Dadia-Lefkimi-Soufli Forest Reserve in Greece. Journal of Sustainable Tourism, 13, 456-467.

Swain, M. \& Swain, M. (2004). An ecofeminist approach to ecotourism development. Tourism Recreation Research, 29, 1-6.

Tao, C., Eagles, P. \& Smith, S. (2004). Profiling Taiwanese ecotourists using a selfdefinition approach. Journal of Sustainable Tourism, 12, 149-168.

Tisdell, C. \& Wilson, C. (2005). Perceived impacts of ecotourism on environmental learning and conservation: turtle watching as a case study. Environment, Development and Sustainability, 7, 291-302.

Twidale, C. \& Bourne, J. (2003). Commentary: practices, problems and principles for ecotourism - a case study. Tourism Geographies, 5, 482-492.

Vincent, V. \& Thompson, W. (2002). Assessing community support and sustainability for ecotourism development. Journal of Travel Research, 41, 153-160.

Wearing, S. (1995). Professionalisation and accreditation of ecotourism. World Leisure \& Recreation, 37, 31-36.

Wearing, S. \& Neil, J. (1999). Ecotourism: Impacts, Potentials and Possibilities. Oxford: Butterworth-Heinemann.

Weaver, D. Ed. (2001a). The Encyclopedia of Ecotourism. Wallingford, UK: CABI. Weaver, D. (2001b). Ecotourism. Brisbane, Australia: Wiley. 
Weaver, D. (2001c). Ecotourism as mass tourism: contradiction or reality? Cornell Hotel and Restaurant Administration Quarterly, 42, 104-112.

Weaver, D. (2002). Asian ecotourism: patterns and themes. Tourism Geographies, 4, $153-172$.

Weaver, D. (2005a). Comprehensive and minimalist dimensions of ecotourism. Annals of Tourism Research, 32, 439-455.

Weaver, D. (2005b). Mass and urban ecotourism: new manifestations of an old concept. Tourism Recreation Research, 30, 19-26.

Weaver, D. \& Lawton, L. (2002). Overnight ecotourist market segmentation in the Gold Coast hinterland of Australia. Journal of Travel Research, 40, 270-280.

Weiler, B. \& Ham, S. (2001). Tour guides and interpretation in ecotourism. In D. Weaver Encyclopedia of Ecotourism (pp. 549-563). Wallingford, UK: CAB International.

Weiler, B. \& Richins, H. (1995). Extreme, extravagant and elite: a profile of ecotourists on Earthwatch expeditions. Tourism Recreation Research, 20, 29-36.

Wight, P. (1993). Ecotourism: ethics or eco-sell? Journal of Travel Research, 31, 3-9.

Wight, P. (1995). Sustainable ecotourism: balancing economic, environmental and social goals within an ethical framework. Tourism Recreation Research, 20 (1), 5-13.

Wight, P. (1996). North American ecotourists: market profile and trip characteristics. Journal of Travel Research, 34, 2-10.

Wight, P. (2001). Ecotourists: not a homogeneous market segment. In D. Weaver Encyclopedia of Ecotourism (pp. 37-62). Wallingford, UK: CAB International.

Wunder, S. (2000). Ecotourism and economic incentives - an empirical approach. Ecological Economics, 32, 465-479. 
Yaman, A. \& Mohd, A. (2004). Community-based ecotourism: a new proposition for sustainable development and environmental conservation in Malaysia. Journal of Applied Science, 4, 583-589.

Yu, D., Hendrickson, T. \& Castillo, A. (1997). Ecotourism and conservation in Amazonian Peru: short-term and long-term challenges. Environmental Conservation, 24, 130-138.

Zeppel, H. (2006). Indigenous Ecotourism: Sustainable Development and Management. Wallingford, UK: CABI.

Zografos, C. \& Kenrick, J. (2005). Negotiating 'indigenousness' through ecotourism in the Amazonian Ecuador. Tourism, 53, 205-215.

Zografos, C. \& Oglethorpe, D. (2004). Multi-criteria analysis in ecotourism: using goal programming to explore sustainable solutions. Current Issues in Tourism, 7, 2043.

Zwirn, M., Pinsky, M. \& Rahr, G. (2005). Angling ecotourism: issues, guidelines and experience from Kamchatka. Journal of Ecotourism, 4, 16-31. 